\title{
Advertisements through unclad babies vis-à-vis their Child Rights
}

\author{
Juhi P. Pathak \\ Junior Research Fellow (UGC), Department of Communication and Journalism, Gauhati University, Assam, \\ India
}

\begin{abstract}
The subject of the use of infants and children in advertising is becoming a major concern in developing and developed countries. There are many organisations and NGOs that have compared children being part of advertisements with child labour. But the topic of this research paper goes far more indepth and tries to see if using clippings of unclad babies will violate their rights of privacy and other related rights. The researcher, through this paper, wants to protect the rights of those babies whose rights are being violated (may be) unintentionally by the Advertisers or their parents because of lack of awareness or lack of proper dwelling on the subject. In fact, the use of babies per se is not only in the form of abuse but also as 'exploitative human objects'. While one is delighted to see babies in advertisements how ethical it is to make them recommend consumer products that too, many a times, in an unclad state, is an important question? The world of advertising uses babies to peddle products related to them but the point to be noted is - will the product sell more if the baby is shown unclad? The second pertinent question is if those babies are being used by the parents for monetary or glamour gains? The third point is just like many of us are ashamed to show our unclad photographs in albums to guests visiting our house, similarly those visuals of the babies, for example a brand showing a baby sitting in a puddle of toilet, can be a reason of their embarrassment when they grow up. This paper takes into consideration the psychological aspect of the babies also when they grow up. The paper studies the present Advertising codes of conduct and if the above points are being catered to by them. We will also take into consideration various International Conventions and the laws of our land regarding Child Rights and if there is any mention of violation of rights in context of the topic of our study.
\end{abstract}

Keywords: Media, Child rights, protection, advertisements, unclad babies, laws, codes

\section{Objectives}

1. To make a content analysis of advertisements wherein babies are used in an unclad or partially covered ways.

2. To make a comparative study of two sets of advertisements wherein in one set messages are disseminated through unclad babies and the other set, where the same messages are portrayed in a decent way.

3. To make an indepth study and see if using clippings of unclad babies will violate their rights of privacy and other related rights.

4. To take into consideration the psychological aspect of the babies used in advertisements when they grow up.

5. The paper studies the present Advertising codes of conduct and if the above points are being catered to by them.

6. To take into consideration various International Conventions and the laws of our land regarding Child Rights and if there is any mention of violation of rights in context of the topic of our study.

\section{Research Question}

Are the rights of privacy, self-esteem and dignity of the child violated if it is portrayed unclad through advertisements?

\section{Research Design}

The research is a Descriptive and Diagnostic one. We have done case studies of advertisements that contain clippings of unclad babies. Moreover it will be an exploratory study as not much literature was available on the topic and the study is this field is a new one so we have to explore the possible ways in which we can protect the rights of those children. The data are mainly collected through secondary sources like books, newspapers, magazines and internet sources and primary sources like interviews. 


\section{Introduction}

Child is nation's asset and future resource of manpower of a nation. Its development with dignity is a matter of great concern throughout the World. The Indian Constitution has also taken care of child by providing the following provisions in Article 39 of the Directive Policies.

The State shall, in particular, direct its policy towards securing-

1. that the health and strength of workers, and the tender age if children are not abused and that citizens are not forced by economic necessity to enter vocations unsuited to their age or strength.

2. that children are given opportunities and facilities to develop in a healthy manner and in condition of freedom and dignity and that childhood and youth are protected against exploitation, and against moral and material abandonment.

The United Nations 'Convention on the Rights of the Child', which has been adopted by the General Assembly of the United Nations on $20^{\text {th }}$ November, 1989 and also acceded by the Government of India in the Convention dated $11^{\text {th }}$ December, 1992, also provides for provisions for the welfare and procedure for punishment of the child.

The Government of India, also in pursuance of the constitutional provisions, evolved a national policy for the welfare of children. This policy starts with a goal-oriented perambulatory introduction:

'The nation's children are a supremely important asset. Their nature and solicitude are our responsibility. Children's programme should find a prominent part in our National plans for the development of human resources, so that our children grow up to become robust citizens, physically fit, mentally alert and morally healthy, endowed with skills and motivations, needed by society. Equal opportunities for development to all children during the period of growth should be our aim, for this would serve our larger purpose of reducing inequality and ensuring social justice.'

But even though we have so many international and national laws to protect the rights of the child, certain seemingly minor aspects are being overlooked which can be a major violation in the rights of a child.

\section{EXPLOITATION OF CHILDREN}

Any exploitation of children in any form has a tendency to exploit them either physically, mentally or otherwise is objectionable. Any attempt in this direction so as to exploit children should be put to an end to, to achieve the goal enshrined by the Indian Constitution makers, which are reflected in various provisions of the Constitution, particularly Articles 21, 39, 41, 45 and 46 of the Constitution.

There are many debates going on for a long time if children acting in advertisements or other media related platform can also be considered as child labours? With the rise of the question many Acts and laws in the name of protecting the child against exploitation also came up. But, nothing contained therein speaks of protecting the dignity of a child whose private parts are being exposed in the television through advertisements. Is it not exploitation of the body of the child? Just because the child is too small to speak for itself and audience enjoy the cuteness of their bodies, they should not be shown unclad on television.

Even the Mannequins are being covered properly before they are being dressed or while changing their outfits, then is it not the duty of Media and Advertisement professionals to protect the dignity of the child and not expose body parts of the child hat can be a reason of embarrassment for the child at a later stage in life.

\section{CHILDREN AND THEIR WELFARE}

To quote a small incident, there is one video in Youtube that shows Princess Diana and Prince Charles with baby William. They were playing with the baby but it suddenly began to wriggle in uneasiness. The princess immediately got up and took the baby inside to change its clothes as it had passed out. The Prince also immediately stood up and told the cameraman that he could smell something so they would only be back after the clothes of the baby were changed.

This small incident shows that how the mother has protected the right to privacy of the baby and took him inside to change the clothes. She could have done it there too where they were sitting thinking that it was only a baby and there is no problem in changing the diaper but, instead, she protected his dignity and selfesteem by not exposing him in front of public.

Children need special protection because of their tender age and physique, mental immaturity and incapacity to look after themselves. There is a growing realisation in every part of the globe that children must be brought up with love, affection, dignity and under tender care and attention, so that they may be able to attain full emotional, intellectual and spiritual stability and maturity and acquire self confidence and self respect.

There has been equally great concern for the welfare of the children at the international level culminating in the Declaration of Rights of the Child adopted by the General Assembly of the United Nations.

The Declaration in its preamble points out that the child by reason of his physical and mental immaturity needs special safeguards and care including appropriate legal protection, before as well as after birth and that mankind owes to the child the best it has to give and proceeds to formulate several principles. It 
provided that the child shall enjoy special protection and shall be given opportunities and facilities, by law and by other means, to enable him to develop physically, mentally, morally, spiritually and socially in a healthy and normal manner and in conditions of freedom and dignity. In the enactment of law for this purpose, the best interest of the child shall be the paramount consideration.

The exposure of the child in advertisements on television is detrimental to the dignity of the child or the baby. The gender of the child might not be shown on screen but it should be kept in mind that during the shoot of the advertisements the child or the baby is exposed to the cast and crew of the advertisement during the shooting process; and that the baby is handled by complete strangers; and there is no fact to confirm that baby is not manhandled, exploited or harassed during the process.

A baby is like a doll that cannot differentiate between right and wrong. Even if it is exploited or harassed on the sets during the unclad state, it will not be able to defend itself or protect itself from it.

Ms. Kalyani Das, Member of ... said, "We can go further indepth into the case and think of untoward happenings like what if the cuteness of the baby lures people to click its pictures or make videos in that unclad state which might later be used for child pornography? I was in USA to see my baby grand-child. I clicked some of her photographs while she was having bath in the tub. Her nanny immediately asked me to delete the photos and told me that the law in the nation was very strict and if anybody saw photos of a nude baby on my phone or camera I might be arrested of being involved in child pornography. I was shocked but happy at the same time that the law there was so stringent to protect the dignity of the child."

\section{Content analysis of Advertisements}

1. A Huggies diaper advertisement that features Kajol with a baby shows that the baby follows the shadow of its mother (Kajol) who directs the kid to see its own shadow on the floor; and she rushes to get her video camera to record the baby playing with its own shadow. But as soon as she starts recording, she finds that the baby is sitting in a puddle of toilet. The voice over says, "Bacche har pal naye kshisho me joote rehte hai lekin gile pan ke vajah se un koshishon me rukawat aasakti hai. Isiliye le aayiye Huggies..." She shuts the video off and changes the kid to Huggies Diaper. The ad ends with a note, "Gilapan nahi toh koshishen kayi."

2. Another advertisement of the product, Huggies Wonder Pants, featuring Kajol with a baby starts with the mother (Kajol) cladding the bare baby with the product and then starts playing with the baby. The baby crawls away from the mother in a fast pace that the mother gets apprehensive that it will hit the wooden frame of the bed but luckily the baby strikes its head against the pillow and is safe to much relief of the mother. The voice over says, "Bacchon ke liye komalta bhari suraksha se badhkar aur kya ho sakta hai?..."

3. Yet another product, Huggies Care, in its Advertisement shows a mother and the baby playing hide and seek. The mother finds the baby but is shocked to see him sitting on its own toilet and splashing it with its hands.

4. Huggies Dry Comfort, in its advertisement shows a boy running around bare bottom and a song, 'Coochikoo' plays in the background. Everyone in the family fiddles with the buttocks of the child which tries to signify that it is soft and dry because it uses the product.

5. Huggies Dry Pants advertises its product and shows the bare bottom of the child with rashs to make the parents aware that it is important to keep the private parts clean and dry so suggests them to use their product.

6. In another ad of Huggies Total Protection product, the mother kisses the child on its bare bottom.

7. Mamy Poko Pants in its advertisements of pant styled diapers shows how the diaper of a baby opens up as it is ill fitting. An animated character suggests that diapers should be pant styled so that it fits well and keeps the baby comfortable. It also uses unclad baby in the advertisement.

8. Pampers Active Baby advertisements also uses unclad babies. In one such advertisement of their pant styled diapers, the baby is seen in an unclad state.

9. In one Pampers Good Morning Advertisement, the baby is shown getting up with a smile on its face and the mother is proud that her baby always gets up with a smile because it wears diapers from Pampers. This advertisement does not show babies in an unclad state. 
10. One Huggies act features a child playing with a ball of wool that slipped away from the mother's hand who was knitting a sweater. The ad does not show the baby in an unclad state and just portrays how happy the child is playing with its parents while putting the product on that is keeping it dry.

As we have seen except in the last two cases, all other advertisements have shown the babies in an unclad state. Now the question is why babies should be shown in an exposed state when the message can be sent even with fully clothed babies? There Right to privacy is violated when they are shown in negative light sitting on and splashing their own toilet. Babies cannot speak for themselves and the elders should respect their privacy and protect their self respect.

\section{Interviews}

During the course of my research on this subject I have spoken to:

1. Ms. Kalyani Das, Member of the Assam State Commission for Protection of Child Rights.

She said, "The topic of the research is very new and it is important that we take such subtle aspects into consideration. I have been working for the protection of the rights of the children for so long but this angle of thought never struck my mind. It is indeed true that the rights of those babies are being violated for personal and business gains. And it is necessary that some action is taken against it."

2. Ms. Kalyani Das referred the name of Ms. Urmimala Sengupta who is the Consultant for Assam State Commission for Protection of Child Rights.

She said, "I believe this is the first time somebody has thought of this aspect of the violation of child rights. It has never been thought of before and I am sure this step will bring to light that such subtle thing that goes unnoticed can also have important impression on the life of a child. The aspect of advertising is still in its budding stage in India and India itself is developing so, we have to wait for many more years for people to understand the importance of such things. Exposing a baby on camera for the whole nation to see and that too in a negative light of it sitting on a puddle of toile which is an artificially created scene is definitely a violation of their rights to privacy and self esteem. Their dignity is being harmed in this way and some action should be urgently taken to put a stop to it. But then again, unless its importance is being highlighted in the media it is hard to say when the time will come when people will themselves realize that what harm they are causing to the dignity of the little ones who cannot speak for themselves."

3. Ms. Kalyani Das referred the name of Mr. Ved Prakash Gautam, Child Protection Officer, UNICEF, Guwahati.

When asked to give his inputs on the topic concerned, all he said was, "For such queries write to Ms. Suchorita Bardhan, Communication officer, UNICEF, Assam, with CC to jmaster@ unicef.org.”

4. Ms. Suchorita Bardhan never responded to my email that I sent her with the request to provide me with some inputs for the research.

5. Then I contacted Ms. Dipa Dixit, Member of National Commission for Protection of Child Rights through telephone and email. She responded quickly to my mail and said, "Thank you for your kind mail. As I mentioned the broadcasters have set up a self regulatory body -"BCCC" in consultation with the Ministry of Information \& Broadcasting. The Council has a chairperson (Justice (Retd.) A.P.Shah and members which consists of experts, representatives from the Broadcasters, representatives from various Govt. Commissions, etc. The Council regulates content of TV programs through its own guidelines. I am sending you Mr. Ashish Sinha's email id (Secretary-BCCC) and am copying him in on this mail. You may consider calling him for the clarifications that you need for your paper. You may give him my reference."

6. Then when I contacted Mr. Ashish Sinha ( Secretary-BCCC), he said, "Thanks for writing to us! However, let me clarify that the Broadcasting Content Complaints Council (BCCC) does not look into advertisement-related complaints. Our jurisdiction extends only to complaints related to content of programmes aired on non-news channels. The competent body for examining ad-related complaints is Advertising Standards Council of India (ASCI) (www.ascionline.org). The person to be contacted is Mr. Alan Collaco, Secretary General, ASCI.” 
He is right that the Broadcasting Content Complaints Council (BCCC) does not look into advertisementrelated complaints but then when one authority recommends another authority we have little scope of doubt about their area of work.

7. Mr. Alan Collaco, Secretary General, ASCI never responded to my email nor did any response come from the email id that they provided for lodging complaints against advertisements.

8. To take the opinion of a Psychiatrist, I spoke to Prof. Dr. Devakumar, M.D., Registered Psychologist and Psychiatrist and Honorary Advisor to American Biographical Institute, USA.

He said, "Let me throw some experiences of mine. When I meet ordinary children I find that there is a change of behaviour in them when they apply make-up and then they change into something else. I have seen pretty girl children turning into fairies after putting on make-up. They have a change of behaviour on the spot. We would not have thought of such a happening might take place. Then there are parents who push the children into modelling of such acts like the ones you said ie. sitting on a puddle of toilet or letting everyone pamper with their private parts etc. where the children will feel a inferiority complex later in life. Yes of course the parents might do it knowingly or unknowingly that by letting their babies do such acts, they are infringing upon their right to privacy, self-esteem and dignity. But the parents might instead think that it is a thing to be proud of that their babies are into modelling and are being shown endorsing products on national television or media. Through this paper, atleast people will realize that how, without anybody realising, the rights of such babies are being violated."

He also added, "Becoming a model at such a tender age might create the urge in them to choose this line as their career and it might also happen that their parents induce them to take up this line as their career choice. We see so many kids coming working in entertainment business but it is very important for their parents and guardians to see that they do not deviate from their studies. Some of such kids, may again, be victim of superiority complexity among other kids of their age or might even suffer from depression, frustration and inferiority complexity if they see their competitor kids achieving much success than them. So, until they are matured enough to handle their profession in a balanced way, they should not be induced to work in a media that does not guarantee a secured career. Depression might also seep in when later in life they realize that in sought of name and fame they remained educationally unsound. So, there are many angles that need to be noticed and the rights of the children should be protected against them."

9. I also contacted the Delhi office of the NGO, CRY (Child Rights and You) but they also did not respond to my email.

10. I also contacted the Media Centre of Unilever to take their justification and opinion for showing unclad babies in the advertisements of their products but they, too, did not bother to respond. The reason is understood.

11. Johnson and Johnson, India was also contacted through email but they did not respond as well.

12. A similar request was sent to Procter and Gamble regarding the advertisements of the product, Pampers. They were the only company to assure that they will take the complaint into notice. Mo Chu, Consumer Relations Representative of Procter \& Gamble replied to my email saying, "Thank you for contacting Procter \& Gamble regarding Pampers. We always welcome feedback from our consumers as a means of assessing attitudes toward our products and service. We are glad to have the opportunity to respond to your concerns."

13. The former Advocate General of Mizoram and also of Assam and presently a Senior Advocate in the Gauhati High Court, Mr. Pranab Pathak said, "The topic chosen for research is a very unique one and will be a new milestone in safeguarding the rights of the babies who are being exposed to the effect that their rights to privacy, dignity and self esteem are being violated."

The most important thing that he said was, "Babies are Doli Incapax. Black's Law Dictionary defines the term as: not of the age of discretion; not possessed of sufficient discretion and intelligence to distinguish between right and wrong..”. 
He added, "Babies, being Doli Incapax, cannot discriminate between right and wrong and here comes in the role of the parents and the authorities concerned. But parents either are not aware of the implications or it may be that they run after glamour and fame of their wards. And the advertisers would often shirk off saying that they do not see any problem if the parents are ready and willing to portray their babies in that way."

14. Karan Ashar, an actor and model, from Mumbai, who endorses many products said, "Well...I think it all depends on the parents. ..they are responsible for whatever its happening good or bad. That's my view."

15. A few mothers and primary school teachers that I spoke to echoed the view that it is a violation of the rights of the child to be shown unclad through advertisements.

16. Mrs. Tandrali Pathak, an author on theosophy and philosophy said, "It is sad that even after 60 years of independence people of India are not aware of their own rights; let alone the rights of others. Men and women, whether from rural or urban areas are not properly aware of their rights and privileges as citizens of India; further more as just human beings. There are various organs of the United Nations who are working on the field of creating awareness on human rights through international conventions and seminars but such efforts should be brought down or narrowed down to grass root levels so that the benefits percolate to even the lowest strata of people."

She added, "I am sure through this paper, there will be awareness that, sometimes looking at bigger things, we overlook certain small but very important aspects regarding the protection of rights, mainly of the children who cannot speak for themselves."

\section{ANALYSIS FROM THE INTERVIEWS}

There are many things that came to fore through the interviews done throughout the period of research on this topic. Some of them are:

1. People holding important positions in various child protection centres, whether of the centre or state governments are not fully aware of their roles. They could not respond to the simple question as to what is their opinion on the issue. What most of them did was refer somebody else for better inputs; who further referred somebody else making a long chain with no fruitful result.

2. It should be seen that the people holding important positions in various child protection centres regularly check their emails and other means of communicating them that they have provided in the internet. It is no use to provide with emails and phone numbers that are obsolete or are never checked.

3. Most companies avoid answering questions that goes against their interest. In this case Procter and Gamble was an exception that had the courtesy to respond to the query and assuring humbly that they would look into the matter.

4. All the International, National and State bodies working for the protection of the rights of the child should see that their volunteers and members have thorough knowledge on the subject and are in a position to express their opinion wherever necessary.

5. Some mothers said that the thought that such advertisements can violate the rights of the babies involved never struck their mind. But now that they realised it, their outlook onwards such advertisements have changed.

6. Awareness of the rights of children should be done at grass-root level.

\section{RELEVANT GUIDELINES ON THE PROTECTION OF THE RIGHTS OF THE CHILD}

1. http://www.unicef.org provides for a factsheet that summarises the important points in the Convention on the Rights of the Child. A few main points are underlined below:

a. Article 3 (Best interests of the child): The best interests of children must be the primary concern in making decisions that may affect them. All adults should do what is best for children. When adults make decisions, they should think about how their decisions will affect children.

b. Article 4 (Protection of rights): Governments have a responsibility to take all available measures to make sure children's rights are respected, protected and fulfilled. When countries ratify the Convention, they agree to review their laws relating to children. They must help families protect children's rights and create 
an environment where they can grow and reach their potential. In some instances, this may involve changing existing laws or creating new ones. Such legislative changes are not imposed, but come about through the same process by which any law is created or reformed within a country.

c. Article 5 (Parental guidance): Governments should respect the rights and responsibilities of families to direct and guide their children so that, as they grow, they learn to use their rights properly. Helping children to understand their rights does not mean pushing them to make choices with consequences that they are too young to handle.

d. Article 16 (Right to privacy): Children have a right to privacy. The law should protect them from attacks against their way of life, their good name, their families and their homes.

e. Article 36 (Other forms of exploitation): Children should be protected from any activity that takes advantage of them or could harm their welfare and development.

f. Article 42 (Knowledge of rights): Governments should make the Convention known to adults and children. Adults should help children learn about their rights, too.

\section{LAWS AND CODES RELATING TO ADVERTISEMENTS IN INDIA}

\section{Code of Advertising Practice ("ASCI Code")}

In 1985, the Advertising Standards Council of India (“ASCI”), a non statutory tribunal, was established that created a self regulatory mechanism of ensuring ethical advertising practices. ASCI is a voluntary Selfregulation council. The members comprise Advertiser's, Media, Advertising Agencies and other Professional/Ancillary services connected with advertising practice. ASCI entertained and disposed of complaints based on its Code of Advertising Practice ("ASCI Code"). This Code applies to advertisements read, heard or viewed in India even if they originate or are published abroad so long as they are directed to consumers in India or are exposed to significant number of consumers in India.

Chapter III Clause 2 states:

Advertisements addressed to minors shall not contain anything, whether in illustration or otherwise, which might result in their physical, mental or moral harm or which exploits their vulnerability. For example,

Advertisements:

(a) Should not encourage minors to enter strange places or to converse with strangers in an effort to collect coupons, wrappers, labels or the like.

(b) Should not feature dangerous or hazardous acts which are likely to encourage minors to emulate such acts in a manner which could cause harm or injury.

(c) Should not show minors using or playing with matches or any inflammable or explosive substance; or playing with or using sharp knives, guns or mechanical or electrical appliances, the careless use of which could lead to their suffering cuts, burns, shocks or other injury.

(d) Should not feature minors for tobacco or alcohol-based products.

(e) Should not feature personalities from the field of sports, music and cinema for products which, by law, either require a health warning in their advertising or cannot be purchased by minors

\section{Cable Television Networks (Regulation) Act, 1955}

Chapter I Section 2 states that the term "programme" means any television broadcast and includes -

(i) exhibition of films, features, dramas, advertisements and serials through video cassette recorders or video cassette players.

\section{Cable Television Networks Rules, 1994}

Advertising Code -

(I) Advertising carried in the cable service shall be so designed as to conform to the laws of the country and should not offend morality, decency and religious susceptibilities of the subscribers.

(2) No advertisement shall be permitted which-

(i) derides any race, caste, colour, creed and nationality;

(ii) is against any provision of the Constitution of India.

(iii) tends to incite people to crime, cause disorder or violence, or breach of law or glorifies violence or obscenity in any way;

(iv) presents criminality as desirable;

(v) exploits the national emblem, or any part of the Constitution or the person or personality of a national leader or a State dignitary;

(vi) in its depiction of women violates the constitutional guarantees to all citizens. In particular, no advertisement shall be permitted which projects a derogatory image of women. Women must not be portrayed in a manner that emphasises passive, submissive qualities and encourages them to play a subordinate, secondary 
role in the family and society. The cable operator shall ensure that the portrayal of the female form, in the programmes carried in his cable service, is tasteful and aesthetic, and is within the well established norms of good taste and decency;

(vii) exploits social evils like dowry, child marriage.

(viii) promotes directly or indirectly production, sale or consumption of-

(a) cigarettes, tobacco products, wine, alcohol, liquor or other intoxicants;

(b) infant milk substitutes, feeding bottle or infant food.

(3) No advertisement shall be permitted, the objects whereof, are wholly or mainly of a religious or political nature; advertisements must not be directed towards any religious or political end.

(3A) No advertisement shall contain references which hurt religious sentiments.

(4) The goods or services advertised shall not suffer from any defect or deficiency as mentioned in Consumer Protection Act, 1986.

(5) No advertisement shall contain references which are likely to lead the public to infer that the product advertised or any of its ingredients has some special or miraculous or super-natural property or quality, which is difficult of being proved.

(6) The picture and the audible matter of the advertisement shall not be excessively 'loud;

(7) No advertisement which endangers the safety of children or creates in them any interest in unhealthy practices or shows them begging or in an undignified or indecent manner shall not be carried in the cable service.

(8) Indecent, vulgar, suggestive, repulsive or offensive themes or treatment shall be avoided in all advertisements.

(9) No advertisement which violates the standards of practice for advertising agencies as approved by the Advertising Agencies Association of India, Bombay, from time to time shall be carried in the cable service.

(10) All advertisement should be clearly distinguishable from the programme and should not in any manner interfere with the programme viz., use of lower part of screen to carry captions, static or moving alongside the programme.

\section{Press Council of India's Norms for Journalistic ethics}

Point 36 that relates to advertisements state:

i) Commercial advertisements are information as much as social, economic or political information. What is more, advertisements shape attitude and ways of life at least as much, as other kinds of information and comment. Journalistic propriety demands that advertisements must be clearly distinguishable from news content carried in the newspaper.

ii) Newspaper should not publish Liquor \& Tobacco Advertisements

No advertisement shall be published, which promotes directly or indirectly production, sale or consumption of cigarettes, tobacco products, wine, alcohol, liquor and other intoxicants.

iii) Newspaper shall not publish advertisements, which have a tendency to malign or hurt the religious sentiments of any community or section of society.

iv) Advertisements which offend the provisions of the Drugs and Magical Remedies (Objectionable Advertisement) Act, 1954, or any other statute should be rejected.

v) Newspapers should not publish an advertisement containing anything which is unlawful or illegal, or is contrary to public decency, good taste or to journalistic ethics or propriety.

vi) Journalistic propriety demands that advertisements must be clearly distinguishable from editorial matter carried in the newspaper. Newspapers while publishing advertisements should specify the amount received by them. The rationale behind this is that advertisements should be charged at rates usually chargeable by a newspaper since payment of more than the normal rates would amount to a subsidy to the paper.

vii) Publication of dummy or lifted advertisements that have neither been paid for, nor authorised by the advertisers, constitute breach of journalistic ethics specially when the paper raises a bill in respect of such advertisements.

viii) Deliberate failure to publish an advertisement in all the copies of a newspaper offends against the standards of journalistic ethics and constitutes gross professional misconduct. 
ix) There should be total co-ordination and communication between the advertisement department and the editorial department of a newspaper in the matter of considering the legality propriety or otherwise of an advertisement received for publication.

$\mathrm{x}$ ) The editors should insist on their right to have the final say in the acceptance or rejection of advertisements, specially those which border on or cross the line between decency and obscenity.

\section{Childline India Foundation}

CHILDLINE India Foundation (CIF) is the nodal agency of the Union Ministry of Women and Child Development acting as the parent organisation for setting up, managing and monitoring the CHILDLINE 1098 service all over the country. CIF is the sole agency/body responsible for establishing the CHILDLINE service in the cities/districts of the country, monitoring of service delivery and finance, training, research and documentation, creating awareness, advocacy as well as resource generation for the service.

They have come out with a law manual writing elaborately on many important issues through which the rights of the children are violated and the laws that are there for protection against the same.

But there was no mention of the topic of our study that rights of these babies are also violated when they are shown in an unclad state through advertisements.

The manual can be read at: http://www.childlineindia.org.in/pdf/Law-Manual.pdf

\section{RELEVANT LAWS FOR THE PROTECTION OF CHILD RIGHTS IN INDIA}

\section{Commissions for the Protection of Child Rights Act, 2005}

This is an Act to provide for the constitution of a National Commission and State Commissions for Protection of Child Rights and Children's Courts for providing speedy trial of offences against children or of violation of child Rights and for matters connected therewith or incidental thereto.

\section{The Juvenile Justice (Care and Protection of Children) Act, 2000}

This Act is the primary legal framework for juvenile justice in India. The Act provides for a special approach towards the prevention and treatment of juvenile delinquency and provides a framework for the protection, treatment and rehabilitation of children in the purview of the juvenile justice system. This law, brought in compliance of Child Rights Convention 1989, repealed the earlier Juvenile Justice Act of 1986 after India signed and ratified Child Rights Convention 1989 in year 1992. This Act has been further amended in year 2006 and 2010. Government of India is once again contemplating bringing further amendments and a review committee has been constituted by Ministry of Women and Child Development which is reviewing the existing legislation. Recent 16 December 2012 Gang rape incident in Delhi has raised a popular demand for amending this law to allow harsher punishments to children involved in serious offences.

\section{The Child Labour Act, 1986.}

The Act prohibits the employment of children below the age of 14 years in hazardous occupations identified in a list by the law. The list was expanded in 2006, and again in 2008.

Other laws related to the protection of the rights of the child are:

4. The Factories Act, 1948

5. The Probation of Offenders Act, 1959

6. The Child Marriage Restraint Act, 1986

7. The Right of Children to Free and Compulsory Education Act of 2009

8. Children Act, 1960

9. Children (Pledging of Labour) Act, 1933

10. Prohibition of Child Marriage Act, 2006

11. Reformatory Schools Act, 1897

12. Young Persons (Harmful Publications) Act, 1956

\section{REVIEW}

After taking an indepth look at all the laws and codes relating to both advertisements and also to the protection of the rights of the child, we have come to the conclusion that are mentioned as follows:

1. No Code of conduct manual relating to advertisements express explicitly that the rights of the child need to be preserved.

2. There is no mention of the rights to privacy, self esteem and dignity of the child. 
3. There is no mention that the child portrayed through advertisements should not be shown in a derogatory manner.

\section{SUGGESTIONS}

We would like to mention certain suggestions that we think can provide some guidelines on the protection of the rights of the children who are portrayed unclad through advertisements. These suggestions are:

1. Organisation like UNICEF should take the matter up and bring it to light so that public and authorities concerned are aware of this aspect through which the rights of the children are being violated.

2. Then comes the role of the NGOs. The NGOs should put pressure on the advertising companies to take the matter into notice.

3. The NGOs along with public should put pressure on the government to take the matter into notice and initiate the process of proper legislations on the matter.

4. All the Codes and norms relating to advertising standards should be amended and those provisions that would protect the rights of privacy, self esteem and dignity should be inserted.

5. The media should focus on this aspect so that the public at large is made aware of this violation of child rights.

\section{Conclusion}

Children being 'Doli Incapax' do not have the power of discretion. They do not know the difference between right and wrong. Their power to logically think and rationalize is also in a dormant stage. So, it is the duty of the parents, guardians and authorities concerned to see that they are brought up with love, care and dignity. Children being the pillars of the nation, it is the responsibility of the government to legislate necessary laws that would protect their interest and secure their rights. The companies selling child-related products should take it as their moral responsibility and not show a child in negative light that would harm its interest. All necessary laws should be enacted and other related codes and laws be amended so that they work together for the protection of rights of the child.

If we all become responsible and work together for the protection of the rights of the child, then our children would feel more secured and protected in our society.

\section{Bibliography}

\section{References}

[1]. Awasthi, S.K. \& Kataria, R.P. (2000). Law relating to Protection of Human Rights.: Orient Pub.

[2]. Bajpai, Asha. (2003). Child Rights in India: Law, Policy, and Practice.: OUP India

[3]. Bueren, Geraldine Van. (1998). The International Law on the Rights of the Child.: Martinus Nijhoff Pub.

[4]. Macklin, M. Carole \& Carlson, Les (1999). Advertising to Children: Concepts and Controversies.: Sage Pub

\section{Websites}

[5]. http://books.google.co.in/books?id=bH33Fgq14AMC\&pg=PA821\&dq=using+babies+in+advertisements+their+child+rights\&hl=en \&sa $=$ X\&ei=X hTUs6wCdHPrQeh-

oCACw\&ved=0CC0Q6AEwAA\#v=onepage $\& \mathrm{q}=\mathrm{using} \% 20 \mathrm{babies} \% 20 \mathrm{in} \% 20$ advertisements $\% 20$ their $\% 20 \mathrm{child} \% 20 \mathrm{rights} \& \mathrm{f}=\mathrm{false}$

[6]. http://www.justice.qld.gov.au/__data/assets/pdf_file/0005/8978/ir-child_employment_guide.pdf

[7]. http://www.unicef.org/violencestudy/pdf/CP\%20Manual\%20-\%20Stage\%201.pdf

[8]. http://www.cry.org/about-cry/media-center/cry-in-news-and-general-articles/Child-artistes-Early-career-or-child-labour.html

[9]. http://www.indianchild.com/childlaws/child-laws-in-india.htm

[10]. http://www.wikigender.org/index.php/Indian_Laws_relating_to_Women_\%26_Children

[11]. http://en.wikipedia.org/wiki/Child labour_in_India\#Child_labour_laws in_India

[12]. https://www.google.co.in/search?newwindow=1\&q=urmimala+sengupta+child+rights\&oq=urmimala+sengupta+child+rights\&gs 1 =serp.3...7606.10969.0.11243.13.13.0.0.0.0.207.1246.8j3j2.13.0.ckp\%2Ckpns\%3D1000...0..1.1.29.serp..6.7.292.028ActoA6UA

[13]. http://www.unicef.org/india/state profiles $4281 . \mathrm{htm}$

[14]. http://thelawdictionary.org/doli-incapax/

[15]. http://www.alrc.gov.au/publications/68.\%20Decision\%20Making\%20by\%20and\%20for\%20Individuals\%20Under\%20the\%20Age $\% 20$ of\%2018/privacy-rights-children-

[16]. http://www.childlineindia.org.in/

[17]. http://www.childlineindia.org.in/1098/1098.htm

[18]. http://www.childlineindia.org.in/1098/b1ecasestudies.htm

[19]. http://www.childlineindia.org.in/cif.htm

[20]. http://www.adstandards.com/en/clearance/childrens/broadcastCodeForAdvertisingToChildren.aspx

[21]. http://www.ascionline.org/index.php/mission.html

[22]. http://asai.ie/selfregulation/

[23]. http://www.ascionline.org/images/pdf/asci_code1new.pdf

[24]. http://www.ascionline.org/index.php/ascicodes.html

[25]. http://www.delhi.gov.in/wps/wcm/connect/DOIT_EXCISE/excise/notified+areas/notified+areas1 